\title{
Viral structural proteins and genome analyses of the rhabdovirus of penaeid shrimp (RPS)
}

\author{
Yuanan Lu, Philip C. Loh \\ Department of Microbiology, University of Hawaii, Honolulu, Hawaii 96822, USA
}

\begin{abstract}
The viral structural proteins of the recently isolated rhabdovirus of penaeid shrimp (RPS), and that of the mammalian vesicular stomatitis virus (VSV) and 3 other fish rhabdoviruses, infectious hematopoietic necrosis virus (IHNV), viral hemorrhagic septicemia virus (VHSV) and rhabdovirus carpio (RC), were comparatively analyzed by sodium dodecyl sulfate-polyacrylamide gel electrophoresis (SDS-PAGE) and Western blot procedures. The number of major bands identified and the profile of the viral polypeptides of RPS resembled that of VSV and RC but were different from that of IHNV and VHSV. Western blot analysis using polyclonal antiserum against RPS identified the viral origin of the 4 major proteins and an extra protein of RPS. Also, the analysis indicated that although RPS is closely related to RC, it is only partially related to IHNV, VHSV, and VSV. The genomic RNA of RPS extracted by the pronase-SDS-urea method and analyzed by polyacrylamide-agarose gel electrophoresis was determined to be a single component having a molecular weight of $3.6 \times 10^{6}$ daltons.
\end{abstract}

KEY WORDS: SDS-PAGE - Rhabdoviruses - RPS · Viral proteins · Viral RNA

\section{INTRODUCTION}

The Rhabdoviridae is a well-defined family of viruses and its members are found in plants, vertebrates (including fish), invertebrates, and arthropods. Four rhabdoviruses, Y-organ virus, Rhabdo-like virus $\mathrm{A}$ (RhVA), Rhabdo-like virus B (RhVB) and Enveloped helical virus (EHV), are known from Crustacea, exclusively in crabs. Except for the first crab rhabdovirus to be found, Y-organ virus, which was from European shore crab Carcinus maenas (Chassard-Bouchaud \& Hubert 1975, Chassard-Bouchaud et al. 1976), these crab viruses were found in blue crab Callinectes sapidus (Jahromi 1977, Yudin \& Clark 1978, Johnson 1984). Studies on these crustacean rhabdoviruses are limited and little is known about their biochemical and biological properties. Recently a new crustacean rhabdovirus named rhabdovirus of penaeid shrimp (RPS) was isolated from cultured penaeid shrimp (Lu et al. 1991) and some biological characteristics of this shrimp rhabdovirus have been described (Lu \& Loh 1992, Lu et al. 1994).

Rhabdoviruses isolated from vertebrates are mainly composed of 4 to 5 structural proteins (Kang \& Prevec 1970, Mudd \& Summers 1970, Wagner et al. 1970).
These viral proteins were named: L (large protein), G (glycoprotein), N (nucleoprotein), NS (nonnucleoprotein) and $M$ (matrix protein) (Wagner et al. 1972). Based on the electrophoretic patterns of the viral structural proteins, viruses belonging to the Rhabdoviridae are classified into 2 major genera, Lyssavirus and Vesiculovirus (Matthews 1982, Wagner 1987). Among the fish rhabdoviruses, members of the lyssavirus group are composed of IHNV (infectious hematopoietic necrosis virus), VHSV (viral hemorrhagic septicemia virus), HRV (hirame rhabdovirus), and SHRV (snakehead rhabdovirus). Members of the vesiculovirus group include RC (rhabdovirus carpio), PFV (pike fry rhabdovirus), EVEX (eel virus European X), and EVA (eel virus of America). The RPS represents the first rhabdovirus isolate from cultured penaeid shrimp; it would be of interest to characterize its viral structural proteins and viral RNA, and to assign its genotype.

\section{MATERIALS AND METHODS}

Cell cultures and viruses. In this study 2 cell lines, epithelioma papulosum cyprini (EPC) and buffalo green 
monkey kidney (BGMK), were employed. Monolayers of EPC cells were grown in Eagle's minimum essential medium (MEM) supplemented with 10\% fetal bovine serum (FBS), $100 \mathrm{IU} \mathrm{ml}^{-1}$ penicillin and $100 \mu \mathrm{g} \mathrm{ml}^{-1}$ streptomycin in tissue culture grade plastic container at $20^{\circ} \mathrm{C}$. The BGMK cells were grown at $37^{\circ} \mathrm{C}$ in a mixture of 2 media, $2 \times$ Leibovitz medium (L-15) and $1 \times$ MEM, plus the same supplements as described above.

$\mathrm{RC}$ and IHNV provided by Professors J. L. Fryer and J. C. Leong, Oregon State University, Corvallis, Oregon, USA, and VHSV received from Dr J. R. Winton, National Fisheries Research Center, Seattle, Washington, USA, were grown in EPC cells. VSV (vesicular stomatitis virus), Indiana strain, received from Dr Sandra Horakami, University of Florida, Gainesville, Florida, USA, was grown in BGMK cells.

Virus purification. Monolayer cultures of EPC cells grown in $150 \mathrm{~cm}^{2}$ tissue culture grade plastic flasks (Corning) were infected with the different viruses at a multiplicity of infection of 0.01 to $0.1 \mathrm{pfu}^{\text {cell }}{ }^{-1}$. Rhabdovirus of penaeid shrimp and RC-infected cultures were incubated at $20^{\circ} \mathrm{C}$ while IHNV- and VHSVinfected cultures were incubated at $18^{\circ} \mathrm{C}$, and VSVinfected cuitures were heid at $37^{\circ} \mathrm{C}$. With the total destruction of the entire cell monolayer (usually 2 to $3 \mathrm{~d}$ postinfection), the infected cultures were frozen and thawed once; the virus was concentrated and purified using the protocol described previously (Lu et al. 1991). A minor modification was further purification of the banded virus by sucrose gradients: 1 discontinuous ( 20 to $50 \%, w / v)$ and 2 continuous (10 to $50 \%, w / v)$ sucrose gradients. Purity of the finally banded viruses was evaluated by transmission electron microscopy and the virus stored at $-70^{\circ} \mathrm{C}$. Concentrations of viral protein and RNA were determined by the methods of Ehresmann et al. (1973).

Polyacrylamide gel electrophoresis. Analysis of viral structural proteins on SDS-PAGE was conducted using a $4 \%$ stacking gel and $10 \%$ resolving slab gel (Laemmli 1970) prepared as described in a manual by Hoefer Scientific Instruments (San Francisco, CA, USA). Viral proteins were dissociated by mixing an equal volume of the purified virus and $2 \times$ denaturing buffer $(0.125 \mathrm{M}$ Tris, pH $6.8,4 \%$ SDS, $20 \%$ glycerol, and $10 \%$ mercaptoethanol), heated in boiling water for $1.5 \mathrm{~min}$, and then chilled in ice. Following the separation of constituent proteins by electrophoresis at $30 \mathrm{~mA} / 200 \mathrm{~V}$ for 3.5 to $4 \mathrm{~h}$, gels were stained with silver nitrate and the molecular weights of the viral proteins were determined by comparing their relative mobility with internal SDS-PAGE molecular weight standards (Bio-Rad Laboratories, Richmond, CA, USA).

Western blot analysis. Following the separation of viral constituent proteins by SDS-PAGE, the banded proteins were immediately transferred to nitrocellu- lose membranes (Bio-Rad) using a modified method of Towbin et al. (1979) at $150 \mathrm{~mA}$ for $1.5 \mathrm{~h}$ in a homemade electrophoretic transfer apparatus. The nitrocellulose membranes were blocked with $5 \%(\mathrm{w} / \mathrm{v})$ nonfat dried milk (Carnation, Los Angeles, CA) in phosphatebuffered saline (PBS), pH 7.4, for $1 \mathrm{~h}$ or overnight at $4{ }^{\circ} \mathrm{C}$ and then rinsed twice in $0.05 \%$ Tween-20/PBS and once with PBS only, at 5 min per wash. After incubation with rabbit anti-RPS IgG diluted in $1 \%(\mathrm{w} / \mathrm{v})$ nonfat milk/PBS for $1 \mathrm{~h}$, the membranes were washed 3 times as above and then treated with secondary antibody, goat anti-rabbit $\operatorname{IgG}(\mathrm{H}+\mathrm{L})$ conjugated with peroxidase (Kirkegaard \& Perry Laboratories, Inc., Gaithersburg, MD, USA) diluted in $1 \%$ nonfat milk/PBS for another $1 \mathrm{~h}$. The membranes were washed again and protein bands on the membranes were visualized by incubating in a freshly prepared $D A B$ substrate [0.5 $\mathrm{mg} \mathrm{ml}^{-1} 3,3^{\prime}$-diaminobenzidine tetrahydrochloride with $0.02 \%(\mathrm{v} / \mathrm{v}) \mathrm{H}_{2} \mathrm{O}_{2}$ in PBS) for approximately $90 \mathrm{~s}$.

Preparation of viral RNA. Viral RNA was extracted by the method of Kelly (1972). Briefly, purified virus was mixed with pronase $\mathrm{E}$ (Sigma) at a final concentration of $50 \mu \mathrm{g} \mathrm{ml}^{-1}$ in a $1.5 \mathrm{ml}$ microcentrifuge tube (Fisher Brand, Fisher Scientific Allied Co.). The mixture was incubated at $37^{\circ} \mathrm{C}$ for $1 \mathrm{~h}$, and then SDS and reagent grade urea crystals were added to a final concentration of $1 \%(\mathrm{v} / \mathrm{v})$ and $4 \mathrm{M}$, respectively. The mixture was then incubated for $10 \mathrm{~min}$ at $37^{\circ} \mathrm{C}$. The SDS was removed by precipitation with $2 \%(\mathrm{v} / \mathrm{v})$ potassium acetate for $20 \mathrm{~min}$ in the cold, followed by slow speed centrifugation at $1000 \times g$ for $10 \mathrm{~min}$. The recovered aqueous phase containing RNA was then transferred to a fresh tube, mixed with 3 volumes of cold $100 \%$ ethanol, and precipitated overnight at $-20^{\circ} \mathrm{C}$. The RNA was recovered by sedimentation at $10000 \times g$ for $10 \mathrm{~min}$ at $4^{\circ} \mathrm{C}$ and was resuspended in a small volume of $1 \times$ Tris-acetate-EDTA buffer $(0.04 \mathrm{M}$ Tris, $0.02 \mathrm{M}$ Na-acetate, and 0.002 M di-Na EDTA, pH 7.8).

Electrophoresis of RNA. A vertical slab unit SE400 (Hoefer Scientific Instruments), an apparatus routinely used for protein analysis, was adopted for the purpose of analyzing the viral genomic RNA. Electrophoresis of RNA was carried out in slab gels consisting of $2 \%$ polyacrylamide $(0.1 \%$ bisacrylamide $)$ and $0.6 \%$ agarose. The gels were prepared by mixing $12.5 \mathrm{ml} 8 \%$ acrylamide, $25 \mathrm{ml}$ of $2 \times$ Tris-acetate-EDTA buffer $(0.08 \mathrm{M}$ Tris, $0.04 \mathrm{M} \mathrm{Na-acetate,} \mathrm{and} 0.004 \mathrm{M}$ di-Na EDTA), and $12.5 \mathrm{ml} 2.4 \%$ agarose (Ultrapure Agarose, electrophoresis grade, Bethesda Research Laboratories, Gaithersburg, MD, USA). The slab gels were allowed to polymerize overnight. The extracted viral RNA samples were mixed with equal volume of gel-dye solution $(0.1 \%$ Bromophenol blue, $50 \%$ sucrose, and 0.1 M EDTA, pH 6.8). RNA molecular-weight marker II (Boehringer, Mannheim, Germany) was used to esti- 
mate the relative mobility of the viral RNAs. Electrophoresis was carried out in $1 \times$ Tris-acetate-EDTA buffer for 2.5 to $3 \mathrm{~h}$ at $150 \mathrm{~V} / 68 \pm 1 \mathrm{~mA}$. After completion of electrophoresis, the gels were stained with silver nitrate. Molecular weights of each of the viral RNA genomes were determined using a standard curve plotted from the relative mobility of VSV RNA and RNA markers as described by Schaffer \& Soergel (1972) and by Repik \& Bishop (1973).

\section{RESULTS}

\section{Viral structural proteins}

The SDS-PAGE separation of the viral structural polypeptides of RPS, VSV, RC, IHNV and VHSV are shown in Fig. 1. The patterns of the viral structural proteins of IHNV and VHSV were identical, consisting of 5 structural polypeptides. The structural protein profiles of VSV and RC were similar, each made of 4 viral structural polypeptides. The estimated molecular weights of their proteins are summarized in Table 1.

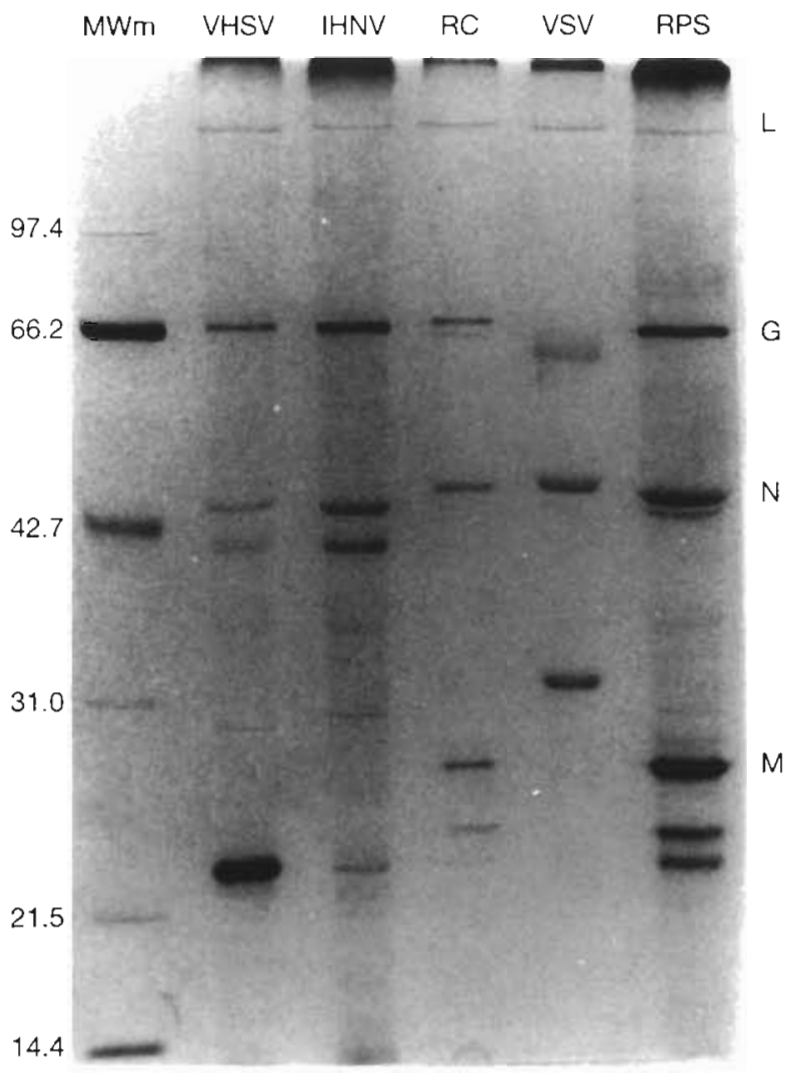

Fig. 1. Electropherograms of viral proteins after electrophoresis for $3.5 \mathrm{~h}$ at constant $200 \mathrm{~V}$ in a $10 \%$ polyacrylamide slab gel and stained with silver nitrate. Lanes from left to right are MWm (molecular weight markers), VHSV, IHNV, RC, VSV, and RPS
Table 1. Estimated molecular weights of viral structural proteins of the viruses RPS, VSV, RC, IHNV, and VHSV based on relative mobility in SDS-PAGE

\begin{tabular}{|cccccc|}
\hline Protein & RPS & VSV & RC & IHNV & VHSV \\
\hline L & 165 & 165 & 165 & 165 & 165 \\
G & 65.7 & 63.2 & 68.6 & 66.2 & 66.5 \\
N & 45.1 & 47.3 & 47 & 44.2 & 44.8 \\
M & 27.8 & 32.2 & 28.3 & & \\
M1 & & & & 30.2 & 29.6 \\
M2 & & & & 23.8 & 22.6 \\
\hline
\end{tabular}

The electropherograms of RPS particles also revealed 4 major viral proteins with the following molecular weights: $165,65.7,45.1$ and $27.8 \mathrm{kDa}$. On the basis of these results the number of structural proteins and their electrophoretic profile of RPS are very similar to those of prototype rhabdovirus, VSV, and of RC, both of which belong to the genus Vesiculovirus, and are different from those of the 2 lyssa-type fish rhabdoviruses, IHNV and VHSV. The latter group of fish rhabdoviruses is easily distinguished from the vesiculogroup in that the matrix proteins are composed of 2 structural polypeptides $\mathrm{M} 1$ and $\mathrm{M} 2$ versus a single polypeptide $M$ in the vesiculo-group.

\section{Western blot}

Western blot analysis of the proteins of RPS separated by SDS-PAGE with anti-RPS polyclonal serum. revealed, in addition to the presence of the 4 major proteins designated L, G, N, and $M$ (Fig, 2), an extra viral protein with a molecular weight of $38 \mathrm{kDa}$ which was not observed in SDS-PAGE. Based on its molecular weight, this polypeptide was presumed to be nonstructural (NS) protein. As shown in Fig. 2, anti-RPS serum exhibited various patterns of reactivity with the structural proteins of VSV, RC, IHNV, and VHSV. Although cross-reactions of the anti-RPS serum were observed with most of the structural proteins of RC, the intensity of reaction to RC was much weaker than that observed for RPS. The antiserum cross-reacted with the $G$ protein of both IHNV and VHSV, and also with the $M$ protein of VSV. The antiserum did not crossreact with the other structural proteins of IHNV, VHSV, and VSV to any detectable extent.

\section{Viral RNA analysis}

The polyacrylamide-agarose gel electrophoresis of the viral RNAs extracted by pronase-SDS-urea treatment of purified RPS and VSV showed consistently 


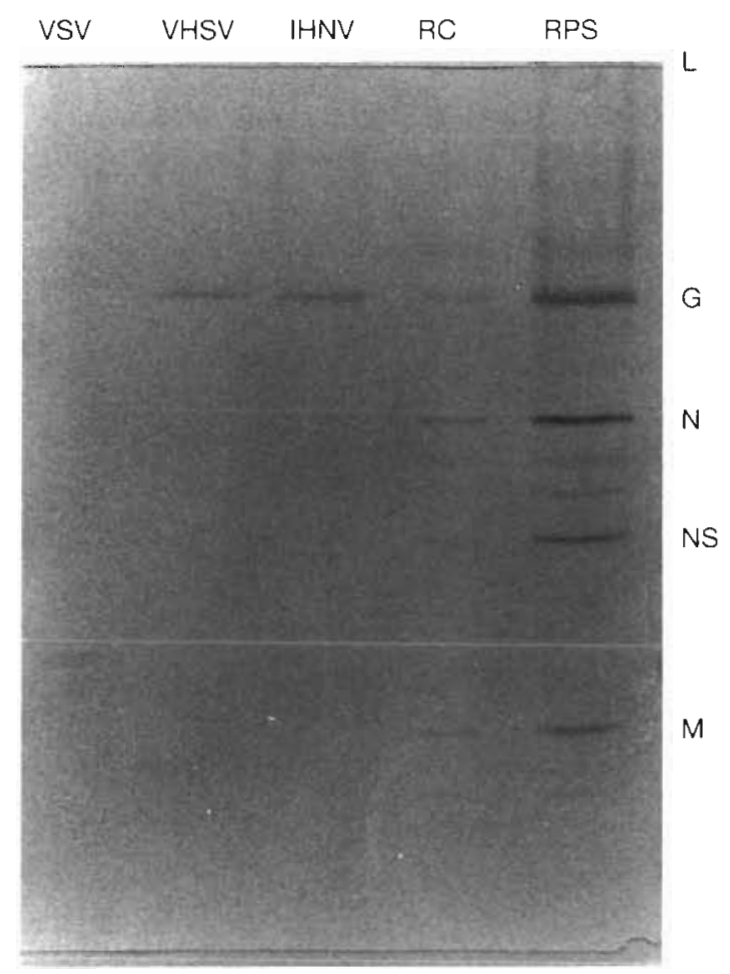

Fig. 2. Western blot analysis of viral structural proteins which were transferred to nitrocellulose membranes and reacted with antiserum against RPS. Lanes from left to right are VSV, VHSV, IHNV, RC, and RPS

single bands (Fig. 3). Under the present experimental conditions, the mobility of RPS-RNA was nearly the same as that of VSV-RNA. Based on RNA molecularweight marker II and the molecular weight of VSVRNA, which is $3.8 \times 10^{6}$ daltons (11 kb) (Bishop \& Roy 1971 ), the molecular weight of RPS-RNA is calculated to be approximately $3.6 \times 10^{6}$ daltons $(10.4 \mathrm{~kb})$.

\section{DISCUSSION}

The SDS-PAGE analysis of viral proteins of rhabdoviruses has been widely used to characterize newly isolated viruses and to identify their relationship to known viruses (Obijeski et al. 1974, Leong et al. 1981, Nishizawa et al. 1991, Kasornchandra et al. 1992). The present study indicates that the viral structural polypeptides and the electrophoretic profile of the crustacean rhabdovirus (RPS) were very similar to those of rhabdoviruses isolated from mammals and fish. The results showed that RPS is composed of 4 major viral structural polypeptides with estimated molecular weights of $165(\mathrm{~L}), 65.7(\mathrm{G}), 45.1(\mathrm{~N})$, and $27.8(\mathrm{M}) \mathrm{kDa}$. The viral structural protein profile of RPS closely resembled that of VSV, the prototype virus of the genus Vesiculovirus, and of RC (a vesiculo-type virus

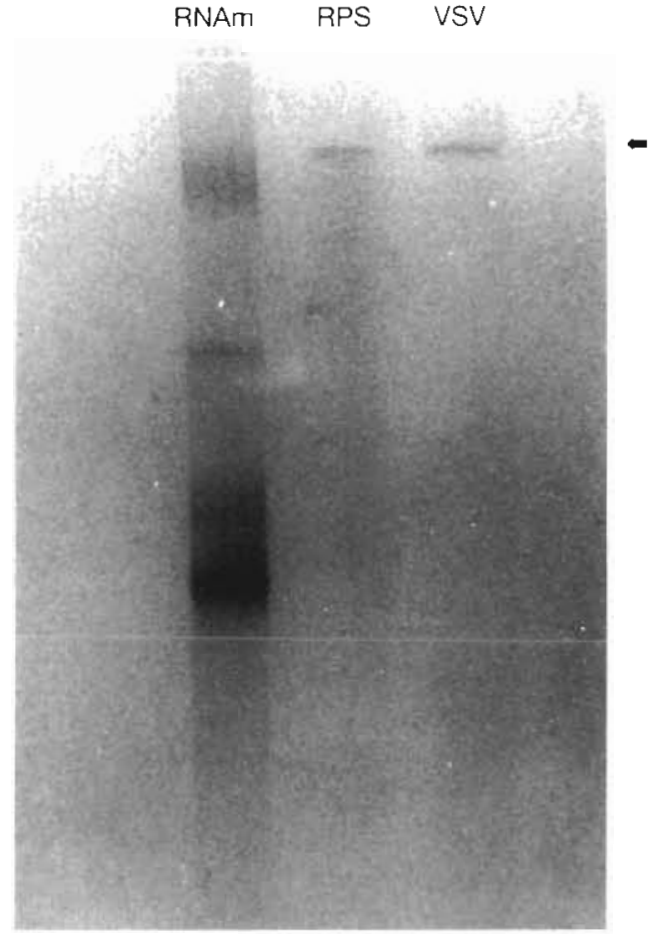

Fig. 3. Electropherograms of acrylamide-agarose slab gel stained with silver nitrate after electrophoresis of the viral RNAs extracted from rhabdovirus of penaeid shrimp (RPS) and vesicular stomatitis virus (VSV). Arrow shows locations of the viral RNA bands. Lanes from left to right are RNAm (RNA markers), RPS, and VSV

isolated from fish), but was clearly distinct from that of IHNV and VHSV (members of the genus Lyssavirus). The data indicate that RPS is a rhabdovirus belonging to the genus Vesiculovirus.

Despite variations in size of some viral structural proteins, the electrophoretic patterns of the viral polypeptides of VSV, RC, IHNV and VHSV shown in this study are quite similar to those observed by others (Jørgensen et al. 1989, Kimura et al. 1989, Nishizawa et al. 1991). The variations observed may have resulted from either strain differences, sample treatment (heating time), or differences in the gel electrophoresis system.

Examination of the antigenic relationship of the shrimp rhabdovirus to VSV and 3 other fish rhabdoviruses by the Western blot technique revealed that the RPS is partly related to VSV, IHNV and VHSV. The anti-RPS serum identified the G protein of both IHNV and VHSV and the M protein of VSV. Although the anti-RPS serum cross-reacted with the structural proteins of $\mathrm{RC}$, suggesting a close evolutionary relatedness of these 2 viruses, the intensity of reaction to the serum between RPS and RC is different. Also, the relative mobilities of the $G, N$, and $M$ proteins of RPS are different from that of $\mathrm{RC}$. These results are consistent with the findings described previously that RPS is 
unrelated to IHNV and VHSV: and is closely related to but serologically distinguishable from RC using the plaque reduction and neutralization kinetics techniques (Lu et al. 1994). By employing the Western blot technique, an extra antigenic protein associated with RPS which was not visible on the SDS-PAGE was detected. This protein has a relative molecular weight of $38 \mathrm{kDa}$ which is equivalent to the NS protein identified for the vesiculoviruses. Failure to detect this viral polypeptide (NS) by SDS-PAGE might be due to its small amount compared to the other structural proteins (Lenoir \& de Kinkelin 1975, Clerx \& Horzinek 1978, Nishizawa et al. 1991, Kasornchandra et al. 1992). The NS protein is a highly variably phosphorylated protein which is involved in viral transcriptional activities. However, other functional activities remain to be recognized (Wagner 1990).

The molecular weight of the RNA genome of RPS appears to fall within the genomic range of 3.1 to $4.4 \times 10^{6}$ daltons determined for other rhabdoviruses (Heyward et al. 1979). It can be assumed that the viral RNA of this shrimp rhabdovirus, like that of VSV, is an unsegmented single strand possessing negative polarity.

The pronase-SDS-urea procedure employed in this study was successful for extracting viral RNAs (Kelly 1972). This method was extremely simple, effective, and easily reproducible. A sample of $50 \mu l$ or less of purified virus suspension could provide enough of the viral RNA (approximately $5 \mu \mathrm{g}$ ) to form a visible band. A vertical slab unit SE400 routinely used for protein analysis in this laboratory was successfully adapted for RPS-RNA analysis. The electrophoresis was carried out in a gel composed of $2 \%$ polyacrylamide and $0.6 \%$ agarose and a single, non-segmented RNA genome was consistently observed after silver nitrate staining. Since this system excluded the use of radioactive labeling, the method is safe to perform. Furthermore, the silver stained gels could be dried for long-term storage.

Acknowledgements. This research was supported by grants from the University of Hawaii Sea Grant and College Program, Institutional Grant No. NA89AA-D-SG063, UNIHISEAGRANT-JC-94-24, and the Aquaculture Development Program, Department of Land and Natural Resources, State of Hawaii Contract No. 34506.

\section{LITERATURE CITED}

Bishop, D. H. L., Roy, P. (1971). Kinetics of RNA synthesis by vesicular stomatitis virus particles. J. molec. Biol. 57: $513-527$

Chassard-Bouchaud, C., Hubert, M. (1975). Sur l'existence de vésicules de réticulum endoplasmique lisse dans l'organe Y de Carcinus maenas L. (Crustacé décapode). C.r. Acad. Sci., Paris, Sér. D 281: 707-709

Chassard-Bouchaud, C., Hubert, M., Bonami, J. R. (1976). Particules d'allure virale associées a l'organe $\mathrm{Y}$ du crabe,
Carcinus maenas (Crustacé, décapode), C.r. Acad. Sci., Paris, Sér. D 282: 1565-1567

Clerx, J. P. M., Horzinek, M. (1978). Comparative protein analysis of non-salmonid fish rhabdoviruses. J. gen. Virol. 40: $287-295$

Ehresmann, B., Imbault, P., Well, J. H. (1973). Spectrophotometric determination of protein concentration in cell extracts containing tRNA and rRNA's. Analyt. Biochem. 54: $456-463$

Heyward, J. T., Holloway, B. P., Cohen, P., Obijeski, J. F. (1979). Rhabdovirus nucleocapsid. In: Bishop, D. H. L. (ed.) Rhabdoviruses, Vol. I. CRC Press, Boca Raton, p. 138-149

Jahromi, S. S. (1977). Occurrence of rhabdovirus-like particles in the blue crab, Callinectes sapidus. J. gen. Virol. 36: $585-493$

Johnson, P. T. (1984). Viral diseases of marine invertebrates. Helgoländer Meeresunters. 37: 65-98

Jørgensen, P. E., Olesen, N. J., Ahne, W., Lorenzen, N. (1989). SVCV and PFR viruses. Serological examination of 22 isolates indicates close relationship between the two fish rhabdoviruses. In: Ahne, W., Kurstak, E. (eds.) Viruses of lower vertebrates. Springer, Berlin, p. 349-366

Kang, C. Y., Prevec, L. (1970). Proteins of vesicular stomatitis virus. II. Immunological comparisons of viral antigens. J. Virol, 6: 20-27

Kasornchandra, J., Engelking, H. M., Lannan, C. N., Rohovec, J. S., Fryer, J. L. (1992). Characteristics of three rhabdoviruses from snakehead fish Ophicephalus striatus. Dis. aquat. Org. 13: 89-94

Kelly, R. K. (1972). Some properties of infectious pancreatic necrosis virus and its replication in a fish cell line from Xiphophorus helleri. Ph.D. dissertation, University of Hawaii, Honolulu

Kimura, T., Yoshimizu, M., Oseko, N., Nishizawa, T (1989). Rhabdovirus olivaceus (Hirame rhabdovinus). In: Ahne, W., Kurstak, E. (eds.) Viruses of lower vertebrates. Springer, Berlin, p. 388-395

Laemmli, U. K. (1970). Most commonly used discontinuous buffer system for SDS electrophoresis. Nature 227:680

Lenoir, G., de Kinkelin, P. (1975). Fish rhabdoviruses: comparative study of protein structure. J. Virol. 16: 259-262

Leong, J. C., Hsu, Y. L., Engelking, M., Mulcahy, D. (1981). Strains of infectious hematopoietic necrosis virus may be identified by structural protein differences. Dev. biol. Stand. 49: 43-55

Lu, Y., Loh, P. C. (1992). Some biological properties of a rhabdovirus isolated from penaeid shrimps. Arch. Virol. 127: $339-343$

Lu, Y., Loh, P. C., Nadala, N. C. B. Jr (1994). Serological studies of the rhabdovirus of penaeid shrimp (RPS) and its relationship to three other fish rhabdoviruses. J. Fish Dis. (in press)

Lu, Y., Nadala, E. C. B. Jr, Brock, J. A., Loh, P. C. (1991), A new virus isolate from infectious hypodermal and hematopoietic necrosis virus (IHHNV)-infected penaeid shrimps. J. virol. Methods 31. 189-196

Matthews, R. E. F. (1982). In: Classification and nomenclature of viruses. Fourth report of the international committee on taxonomy of viruses. Karger, Basel, p. 109-114

Mudd, J. A., Summers, D. F. (1970). Protein synthesis in vesicular stomatitis virus-infected HeLa cells. Virology 42 : $328-340$

Nishizawa, T., Yoshimizu, M., Winton, J., Ahne, W., Kimura, T. (1991). Characterization of structural proteins of hirame rhabdovirus, HRV. Dis. aquat. Org. 10: 167-172

Obijeski, J. F., Marchenko, A. T., Bishop, D. H. L., Cann, B. W., Murphy, F. A. (1974). Comparative electrophoretic analy- 
sis of the virus proteins of four rhabdoviruses. J. gen. Virol. 22: $21-33$

Repik, P., Bishop, D. H. L. (1973). Determination of the molecular weight of animal RNA viral genomes by nuclease digestions. I. Vesicular stomatitis virus and its defective T particle. J. Virol 12: 969-983

Schaffer, F. L., Soergel, M. E. (1972). Molecular weight estimates of vesicular stomatitis virus ribonucleic acids from virions, defective particles, and infected cells. Arch. ges. Virusforsch. 39: 203-222

Towbin, H., Shaehelin, R., Gordon, J. (1979), Electrophoretic transfer of proteins from polyacrylamide gels to nitrocellulose sheets: procedure and some applications. Proc. natn. Acad. Sci, U.S.A. 76: 4350-4354

Responsible Subject Editor: J. Stewart, Dartmouth, N.S., Canada
Wagner, R. R. (1987). The rhabdoviruses. Plenum Press, New York

Wagner, R. R. (1990). Rhabdoviridae and their replication. In Fields, B. N., Knipe, D. M. (eds,) Virology. Raven Press, New York, p. 867-881

Wagner, R. R., Prevec, L., Brown, F., Summers, D. F., Sokol, F., Macleod, R. (1972). Classification of rhabdovirus proteins: a proposal. J. Virol. 10: 1228-1230

Wagner, R. R., Snyder, R. M., Yamazaki, S. (1970). Proteins of vesicular stomatitis virus: kinetics and cellular sites of synthesis. J. Virol. 5: 548-558

Yudin, A. I., Clark, W. H. (1978). Two viruslike particles found in ecdysial gland of the blue crab, Callinectes sapidus. J. Invertebr. Pathol. 32: 219-221

Manuscript first received: February 7, 1994 Revised version accepted: May 20,1994 